\title{
PARTNERSHIP AGREEMENTS FOR CONTINUATION OF AN ENTERPRISE AFTER THE DEATH OF A PARTNER
}

\author{
BY WARNER FULLER $\dagger$
}

UNMISTAKABLE signs of expanded use of the partnership device have recently made their appearance in the field of small enterprise. This renewed interest is clearly attributable to the fact that the costs of cloing business frequently are less where this time-honored business unit is used in place of the heretofore more popular corporation. In recent years, the latter has been a favorite source of revenue for constantly mounting costs of government. And as corporate taxes rose without corresponding increases being levied against those using the partnership, the time came when the incentive was strong to re-evaluate the comparative advantages of the two business institutions. ${ }^{1}$ Where the small enterprise has been concerned, the decision has, with increasing frequency, been renclered in favor of the partnership.

Increased use of the partnership makes it probable that in the future greater attention will be paid to the possibility of eliminating or minimizing important disadvantages usually regarded as necessarily incident to the partnership. The natural objective of these efforts will be to obtain for the partnership as many as possible of the advantages of incorporation without actual incorporation. One great corporate advantage not possessed by the partnership is that of so-called "immortality." The legal existence of the corporation is unaffected by the death of one or more of its members. On the other hand, the death of a partner is said to effect a dissolution of the partnership, ${ }^{2}$ and, as a general rule, to cause

$\dagger$ Professor of Law, Washington University School of Law, St. Louis.

1. The appalling complexity and infinite variations of federal and state tax laws, together with the influence of the financial set-ups of particular enterprises and their owners on the amount of tax liability, make impossible any accurate statement covering the tax advantage of the partnership over the corporation. It can safely be said, however, that in a large number of situations a very considerable advantage may be found. See Comment (1939) 23 MinN. L. Rev. 506. It has been broadly estimated that closely owned corporations operating in Illinois would save approximately one-half of their taxes by a shift to a partnership form. Metzdorf, $A$ "Pardner" or Incorporation (1940) 37 COMMERCE 16.

2. CRANE, Partnership (1938) 333. A number of states have statutes authorizing the continuance of a decedent's business by his executor or administrator. Adelman, The Power to Carry on the Business of a Decedent (1937) 36 Micr. L. Rev. 185, 195. They do not, however, authorize the personal representative to continue the enterprise in partnership with the surviving partner. Altgelt v. Sullivan \& Co., $79 \mathrm{~S}$. W. 333 (Tex. Civ. App. 1903); Altgelt v. Alamo Nat. Bank, 98 Tex. 252, 83 S. W. 6 (1904). 
a sudden and enforced liquidation of the business ${ }^{3}$ which can rarely be consummated without substantial losses both to the survivor and to the decedent's estate. ${ }^{4}$ The toll is likely to be especially great, for example, where the venture is one having a valuable good will, or assets such as buildings, inventories, fixtures, and expensive mechanical equipment which are not ordinarily susceptible of advantageous sale on quick liquidation.

The utility of the partnership as a business device will be greatly increased if the unfortunate consequences of a partner's death can be overcome or substantially minimized. Attempts to achieve this end have taken several forms. One scheme has been for one or more of the partners to authorize continuance of the business by testamentary direction. This arrangement may be satisfactory where the terms of the will are agreeable to the survivor. But since the provisions are not binding upon him, ${ }^{6}$ this type of continuation arrangement bears the risk that the survivor will refuse to continue the enterprise on the specified terms. Another possible solution is an agreement between the partners providing that the survivor shall purchase, or have an option to purchase, the decedent's interest upon the latter's death. ${ }^{7}$ This scheme will be satisfactory where the survivor is willing and financially able to assume a definite commitment of purchase. But it will not be useful in those situations where the survivor is unwilling or unable to assume the purchase obligation or where the partner desires to assure his beneficiaries of a continued participation in the profits of the enterprise after his death.

Another plan to minimize the effect of a partner's death provides for an agreement authorizing the continuance of the enterprise after a member's death for the benefit both of the surviving partner or partners ${ }^{8}$

3. 1 Rowley, PARTNERSHIP (1916) \$579. A provision in a partnership agreement that it shall continue for a specified term of years does not authorize the continuance of the enterprise after the death of a partner. Hoard v. Clum, 31 Minn. 186, $17 \mathrm{~N}$. W. 275 (1883); see Scholefield v. Eichelberger, 7 Pet. 586, 594 (U. S. 1833).

4. After a partner's death, absent an agreement or provision in a will authorizing a continuance of the enterprise, there can be but limited continuance for the purpose of winding up. 2 Rowley, Partwership (1916) $\$ 615$. The continuance for this purpose does not in most cases provide a fully satisfactory method of liquidation. See Adelman, The Power to Carry on the Business of a Decedent (1937) 36 Mrcr. L. Rer. 185, 186.

5. See Burwell v. Mandeville's Ex'r, 2 How. 560 (U. S. 1844); Jones v. Wialker, 103 U. S. 444 (1880); Roessler's Estate, 5 Pa. Dist. 776 (1896).

6. Mamaux's Estate, $274 \mathrm{~Pa} .533,103$ Atl. 892 (1922); Slater v. Slater, $203 \mathrm{App}$. Div. 567, 572, 204 N. Y. Supp. 112, 116 (1st Dep't 1924).

7. See Míurphy v. Murphy, 217 Mass. 233, 104 N. E. 466 (1914); Mckinnon v. McKinnon, 56 Fed. 409 (C. C. A. 8th, 1893) ; Harbster's Appeal, 125 Pa. 1, 17 Atl. 204 (1889). Such arrangements may involve leaving decedent's capital in the business in the form of a loan.

8. In order to avoid repetition of the phrase "surviving partner or partners," "surviving partner" will be used as indicating the plural unless the context indieates that a single survivor is meant. 
and the decedent's estate or other persons named by the decedent partner. ${ }^{0}$ This arrangement not only averts sudden liquidation of the business, but also enables the associates to provide for continued payment of the enterprise's profits to their beneficiaries. These rather obvious advantages make it natural to expect that the use of this type of arrangement will increase unless it runs up against legal or practical disadvantages. ${ }^{10}$

The last-mentioned type of continuation arrangement must be varied to meet the particular requirements of specific situations. Where the business is one in which either partner is willing and able to continue in active charge after the other's death, and other considerations do not require the introduction of a third person to succeed to the decedent's place, the simplest plan is to have the survivor ${ }^{11}$ continue the enterprise, operating it on an agreed basis jointly for himself and for the decedent's beneficiaries. ${ }^{12}$ Where, however, only one of the partners is competent to manage the business, the situation seems to call for an arrangement permitting continuation of the enterprise only if the competent partner

9. Such agreements usually provide that the beneficiaries shall be designated by will or other written instrument. Another arrangement is one in which the survivor has the option of paying a specified proportion of the profits or an annuity of a prescribed amount. See Ex parte Harper, 1 De G. \& J. 180 (1857).

10. Whether arrangements of this type give rise to an "association," as distinguished from a partnership, presents an important tax problem. The income of an "association" is taxed under federal income tax statutes in the same way as a corporation, whereas partnership income is regarded as the personal income of the partners. 4 PAUL \& MERtens, Law of Federal Income Taxation (1934) 228 et seq. It seems to have been assumed that a partnership and not an "association" exists where the members operatc their business along orthodox partnership lines, although they may have agreed that the enterprise should be continued to the end of the agreed term, despite the carlier death of a member. James Brown, 10 B. T. A. 1036 (1928). It is improbable that the courts will reach a contrary result. See 4 Paul \& Mertens, Law of Federal Income TAxAtion (1934) 250, 252; Wood v. United States, 55 F. (2d) 733 (E. D. Pa. 1931); IX-1 Cum. Bull. 219. But see III-2 Cum. Bulc. 1. Even if such an arrangement should be treated as an "association," appreciable tax savings over the corporate form can still be afforded through the elimination of state incorporation, annual franchise and capital stock taxes, and federal taxes such as initial and transfer taxes on share certificates and old age taxes. 49 Stat. 636 (1939), 42 U. S. C. $\$ 1004$ (1935 Supp.). Savings may also be effected through elimination of clerical and attorney's costs incident to the preparation and filing of the numerous corporate reports required not only in connection with the foregoing taxes but also in other miscellaneous corporate matters, such as annual reports concerning the corporation's financial status (required in some states). Sce United Oil Co. v. Eager Transp. Co., 273 Mass. 375, 173 N. E. 692 (1930).

11. Sometimes an option to decide whether the business shall be continued is given to the surviving partner. In re Borden's Estate, 95 Misc. 443, 159 N. Y. Supp. 346 (Surr. Ct. 1916). At other times it is given to the decedent partner's beneficiary. Jacquin v. Buisson, 11 How. Pr. 385 (N. Y. Super. Ct. 1878) (although arrangement held invalid, it clearly would be upheld elsewhere. See p. 206 infra).

12. An arrangement found in Bell v. Hepworth, 134 N. Y. 442, 31 N. E. 918 (1892) and Brew v. Hastings, 196 Pa. 222, 46 Atl. 257 (1900). 
should be the survivor. ${ }^{13}$ On the other hand, if either partner has a wife, ${ }^{14}$ son, ${ }^{15}$ relative, or other person whom he desires to succeed to his interest after his death, for the purpose either of safeguarding the interests of his estate or of providing a business career for a beneficiary, the arrangement is likely to involve the introduction of a successor partner. ${ }^{16}$ It is common practice in continuation agreements of the successor partner type to limit the range of selection of successors to persons or classes of persons agreed upon in advance, such as named executors, sons, or relatives, possessing good moral character. ${ }^{17}$ These precautions are essential as a practical matter because of the extremely broad powers which partners possess to subject their associates to unlimited personal liability. Continuation agreements of the kind under consideration generally provide that the venture shall continue either for the term prescribed in the original partnership or for some stipulated period following the death of a partner. ${ }^{18}$

\section{Validity of Continuation Agreenents ${ }^{10}$}

A. Where enterprise is to be continued by sureizing partner without the introduction of a successor partner to replace decedent. An agree-

13. This type of agreement is seen in Gratz $v$. Bayard, 11 S. \& R. 41 (Pa. 1824) and Ponton v. Dunn, 1 Russ. \& 11. 402 (1830).

14. See Balmain v. Shore, 9 Ves. 500 (1804) (agrcement that partner's interest should, upon his death, go to his widow for life and, after her decease, equally to his children, held not to constitute settlement on children predeceasing widow).

15. If the son is a minor, provision is sometimes made for the appointment of an adult to assist in the business until the beneficiary attains his majority. Pemberton Oakes, 4 Russ. 154 (1827). See 2 Rowley, PArTarership (1916) $\$ 1160$ for a suggested form of agreement covering this situation. See also Wainwright v. Waterman, 1 Ves. 211 (1791) for the consequences flowing from the failure of a decedent partner's exceutors to designate a successor partner under the provisions of a continuation agreement.

16. In all these situations, the advisability should be considered of including a provision in the continuation agreement permitting the admission of new or the retirement of old partners. In the absence of such permission, a change in the membership may be held to revoke the decedent's consent to a continuation of the enterprise. See Smith v. Ayer, 101 U. S. 320 (1879).

17. See, for example, Madgwick v. Wimble, 6 Beav. 495 (1843). A provision that the executor of the decedent's estate shall become a partner in decedent's place is also common.

18. See, for example, Bell v. Hepworth, 134 N. Y. 442,31 N. E. 918 (1892) (five years).

19. An agreement of continuance will not be presumed. See Scholefield v. Eichelberger, 7 Pet. 586, 594 (U. S. 1833) ; Burwell v. Mandeville's Ex'r, 2 How. 560, 573 (U. S. 1844) ; Wilcox v. Derickson, $168 \mathrm{~Pa} .331,336,31$ Atl. 1080, 1081 (1S95). Where it is doubtful whether an agreement of partnership contemplates continuation of the business, the question is for the jury. McNeish v. U. S. Hulless Oats Co., 57 Vt. 316 (1884); cf. Alexander's Ex'rs v. Lewis, 47 Tex. 481, 487 (1877).

The surviving partner is, of course, limited in his activities to the scope of the original enterprise. See National Bank of Newburgh v. Bigler, 83 N. Y. 51,57 (1850); 
ment for the continuation of an enterprise after the death of a partner is valid on ordinary contract principles. ${ }^{20}$ It is binding upon the surviving partner, whose failure to abicle by its terms will subject him to an action for damages for breach of contract. ${ }^{21}$ This result seems proper not only on a contract basis, but also in the light of an obviously sound economic policy which has as its objective the minimization or avoidance of the severe business losses which frequently attend the death of a partner.

It is unlikely that the courts will decree specific performance of continuation agreements. Equity ordinarily will not specifically enforce contracts which involve the exercise of special skills and judgment, or demand constant supervision by the courts. ${ }^{22}$ If continuation of the

cf. Berry v. Folkes, 60 Miss. 576 (1882). His authority to act seems to terminate at the end of the prescribed term of continuance. Cf. Steiner \& Lobman v. Steiner Land \& Lumber Co., 120 Ala. 128, 144, 26 So. 494, 498 (1897). It is suggested in Lincoln v. Orthwein, $120 \mathrm{Fed} .880,885$ (C. C. A. 5th, 1903) that if a surviving partner enters into a contract which extends beyond the time specified for continuing the business, the decedent's estate is, upon a breach of the contract, liable only for such damages as accrued prior to the expiration of the term of continuance.

20. Gerding v. Baier, 143 Md. 520, 122 Atl. 675 (1923). See Wild v. Davenport, 48 N. J. L. 129, 136, 7 Atl. 295, 299 (1886); Leaf's Appeal, 105 Pa. 505, 513 (1884); Vincent v. Martin, 79 Ala. 540, 545 (1885); 2 Rowley, Partnership (1916) $\$ 638$; Story, Partnership (6th ed. 1868) § 199.

The validity of such agreements may not be free from doubt in New York. Sce Jacquin v. Buisson, 11 How. Pr. 385 (N. Y. Super. Ct. 1878); Bell v. Hepworth, 134 N. Y. 442,31 N. E. 918 (1892) ; Nat. Bank of Newburgh v. Bigler, 83 N. Y. 51, 57 (1880). See also Hart \& Co. v. Anger \& Nicol, 38 La. Ann. 341 (1886); Louisiana Bank v. Kenner's Succession, 1 La. 384 (1830).

It has been urged that continuation arrangements of the type under consideration are violative of the Statute of Wills. Bell v. Hepworth, supra at 447. No cases have been found, however, which invalidated such agreements on this ground, and this contention was rejected in a well-considered case involving an agreement for purchase of a decedent's interest by a surviving partner. McKinnon v. McKinnon, 56 Fed. 409 (C. C. A. 8th, 1893); Murphy v. Murphy, 217 Mass. 233, 104 N. E. 466 (1914). Contra: Ferrara v. Russo, 40 R. I. 533, 102 Atl. 86 (1917).

21. See Downs v. Collins, 6 Hare 418, 441 (1848); Wild v. Davenport, 48 N. J. L. 129, 137, 7 Atl. 295, 298 (1886); Stearns v. Brookline, 219 Mass. 238, 240, 107 N. E. 57, 58 (1914) ; 2 Rowley, PARTNERSHIP (1916) \$638. Authority for the basis of ascertaining such damages seems completely absent. A persuasive analogy, though, is afforded by cases involving actions among living partners for damages for wrongful termination of a partnership prior to the expiration of the agreed term. The problem of computing damages for breach of post-mortem continuation agreements would seem to be no more difficult than in this situation, despite the fact that in the continuation agreement situation one of the partners is dead and can no longer be considered a factor in the business. See, in particular, Crittenden v. Johnston, 7 App. Div. 258, 40 N. Y. S. 87 (1st Dep't 1896); Treat v. Hiles, 81 Wis. 280, 50 N. W. 896 (1892); cf. Ramsay v. Meade, 37 Colo. 465, 86 Pac. 1018 (1906). But see Webster v. Beau, 77 Wash. 444, 137 Pac. 1013 (1914).

22. The reasons which have been advanced for denying specific performance of a partnership agreement among living partners seem to apply with equal force to the situa- 
business should become impractical for any reason, continued performance on the part of the survivor probably would be excused on the theory that the presumed intent of the parties would be to wind up the enterprise in such circumstances even though the prescribed term had not yet expired. ${ }^{23}$

Agreements of this sort are likewise binding upon the decedent's estate $^{24}$ and upon the personal creditors of the deceased partner. ${ }^{25}$ Any material violation of the agreement by the estate will subject it to a claim for damages by the survivor. ${ }^{26}$ Agreements which contemplate that the survivor alone will continue the enterprise usually provide that the decedent member's interest in the enterprise shall be left in the business until the expiration of some agreed period of time. ${ }^{2 \pi}$ Opinion appears to differ as to whether the estate possesses the power (as distinguished from the privilege) of withdrawing this interest through a court action for compulsory winding up of the business. Some authorities seem to indicate that the estate has neither the power nor the privilege of withdrawing the decedent's interest where the business is to be carried on alone by

tion where a surviving partner is unwilling to continue the business after the death of his associate. It has been said with respect to the former situation that equity will not enforce a contract requiring the exercise of the business slill and judgment so characteristic of the partnership relation. See Buck v. Smith, 29 Mich. 166, 171 (1874); Clark v. Truitt, 183 Ill. 239, 245, 55 N. E. 683, 685 (1899); 5 Poxseror, Equitr JurisPRUDENCE (4th ed. 1918) 4898. Some states deny specific periormance of an agreement contemplating the existence of a partnership over a designated period of years because its enforcement would require continuous court supervision during the life of the agreement. 5 Posreroy, Equity Jurisprudence (4th ed. 1918) 4898. But see Jones v. Parker, 163 Mass. 564, 40 N. E. 1044 (1895). The usual contention concerning the adequasy of the legal remedy doubtless also would be involed to defeat a suit of this type.

23. See In re Clift's Estate, 135 Misc. 4, 10 (1929), 237 N. Y. Supp. 635, 643; cf. Lindley, Partnership (10th ed. 1935) 677.

24. Brew v. Hastings, $196 \mathrm{~Pa} .222,46$ Atl. 257 (1900) ; cf. Gerding v. Baier, 143 Md. 520, 122 Atl. 675 (1923). See also Burwell v. Mandeville's Ex'r, 2 How. 560, 561 (U. S. 1844) ; Wild v. Davenport, 48 N. J. L. 129, 137, 7 Atl. 295, 299 (1886); Sterns v. Brookline, 219 Mass. 238, 240, 107 N. E. 57, 58 (1914). But see Buclingham v. Morrison, 136 I11. 437, 454, 27 N. E. 65, 68 (1891) (suggestion that agreement does not bind decedent's heirs); Laughlin v. Lorenz, $48 \mathrm{~Pa}$. 275, 282 (1864) (suggestion that agreement binds the estate only if executor consents).

25. Brew v. Hastings, $196 \mathrm{~Pa} .222,46$ Atl. 257 (1900). This result seems sound. The deceased partner in these circumstances has contracted that his financial interest shall be left in the partnership for an agreed term. His creditors may, of course, prove their claims against his estate, and his interest in the partnership could, as a part of his estate, presumably be subject to the payment of such claims. See Bell v. Hepworth, 134 N. Y. 442, 448, 31 N. E. 918,921 (1892).

26. See Sterns v. Brookline, 219 Mass. $238,240,107$ N. E. 57,58 (1914); Wild v. Davenport, 48 N. J. L. 129, 137, 7 Atl. 295, 299 (1886).

27. This situation must be carefully distinguished from that in which the continuation agreement contemplates that decedent's executor or other designated person shall succeed to the decedent as successor partner. See p. 209 infra. 
the survivor of two partners. ${ }^{28}$ Others seem to suggest that the estate may demand a winding up of the business, although such a move would subject it to an action for damages on the part of the survivor. ${ }^{20}$

If withdrawal is not permitted, the result is tantamount to specific performance of the estate's part of the agreement. This would seem to be the sounder result. The usual argument against specifically enforcing partnership contracts is that it is undesirable to coerce persons into the continuation of complex and confidential relationships where, as in the partnership, the associates possess such wide powers to subject each other to formidable personal liability. ${ }^{30}$ This argument has little, if any, application to the situation under consideration. There is no opportunity for disagreement as to the control of the business, as that is vested in the survivor by agreement, and no personal liability falls on unwilling shoulders, since neither the decedent's executors nor his heirs become liable for the debts of the continued business. ${ }^{31}$ Furthermore, where the surviving partner is willing to carry out the arrangement, no burden of continued supervision is imposed upon the courts. This result, which strengthens continuation agreements by preventing the estate from breaching the partnership contract, has the additional advantage of enabling men to plan for the future with confidence that their wishes will be carried out.

The estate will doubtless be excused from proceeding under a continuation agreement in instances where the survivor is guilty of misconduct in the management of the enterprise, ${ }^{32}$ or where the agreement for continuance is so indefinite as to make it impossible to ascertain its material terms, such as the amount of capital to be left in the business. ${ }^{3 a}$

B. Where continuation agreement contemplates that a successor partner will take place of decedent member. A continuation agreement may

28. See Wilcox v. Derickson, 168 Pa. 331, 335, 31 Atl. 1080, 1081 (1895); cf. Burwell v. Mandeville's Ex'r, 2 How. 560, 576 (U. S. 1844); Lincoln v. Orthwein, 120 Fed. 880, 883 (C. C. A. 5th, 1903) ; Owens v. Mackall, 33 Md. 382, 396 (1870). Although these cases, with the exception of Wilcox v. Derickson, supra, involve situations in which the business was continued pursuant to testamentary direction rather than by contractual arrangement; they afford support for the statement, because the case for requiring a decedent's capital to be left in the business is obviousiy stronger where provided for by contract than where the testator has merely directed a continuance by will.

29. See Wild v. Davenport, 48 N. J. L. 129, 137, 7 Atl. 295, 300 (1886).

30. 2 Rowley, Partnership (1916) §778.

31. Compare this result with that where it is contemplated that a successor partner shall be introduced into the business but where the named person refuses to act. See p. 209 infra.

32. Parnell v. Thompson, 81 Kan. 119, 105 Pac. 502 (1909).

33. This is on the basis that a contract does not become legally binding where a material term is so indefinite as to make it impossible to ascertain the intention of the parties. 1 Williston, Contracts (rev. ed. 1936) $\$ 37$; cf. Downs v. Collins, 6 Hare 418 (1848). 
differ from the type just considered in that it may contemplate the introduction into the enterprise of a successor partner to replace the decedent member. Where this plan is adopted, it is commonly provided that the new or successor partner shall be the decedent's personal representative, perhaps his widow, son, or other relative, and that the successor partner shall carry on the business with the survivor for the benefit of the decedent's estate. Such agreements commonly provide that each of the original partners shall have the duty or option of nominating a successor before his death. ${ }^{34}$ If a partner dies and the nomination has been properly made, the nominee has a reasonable time to look into the affairs of the partnership and to decide whether he will become a partner. ${ }^{35}$ If a nomination is made in accordance with the terms of the agreement ${ }^{36}$ and both the nominee and the surviving partner are willing to continue the business, they will be permitted to do so over the objection of the decedent's heirs. $^{37}$ The surviving partner may, however, be unwilling to continue the enterprise. If he refuses to abide by his contract, he becomes subject to damages for breach of contract, ${ }^{38}$ but he cannot and should not be coerced into carrying on the business in partnership with the person designated. The same reasons which preclude specific performance of the ordinary partnership contract among living partners are plainly applicable here ${ }^{39}$ The consequence of the refusal of a surviving partner to continue the business will be liquidation. ${ }^{40}$

It may happen, of course, that the party who refuses to continue the business is the person who has been designated as the successor partner. If the agreement is one which expressly names the successor partner or which imposes a duty on a partner to nominate a successor in his

34. Where such nomination is actually made prior to the death of a partner, it would seem that the nominee gets no such interest in the business as would prevent the original partners from thereafter dissolving the partnership. Ehrmann v. Ehrmann, 72 L. T. 17 (1895).

35. Pigott v. Bagley, M'Clel. \& Y. 569 (1825); IVild v. Davenport, $4 S$ N. J. L. 129, 7 Atl. 295 (1886). But the nominee cannot require a partnership accounting. Pigott v. Bagley, stipra.

36. Holland v. King, 6 C. B. 727 (1848); cf. Evans v. Watts, 192 Pa. 112, 43 Atl. 464 (1899).

See Ponton v. Dunn, 1 Russ. \& Mr. 402 (1830) as to the consequence of a decensed partner's failure to name the beneficiary of the continued business.

37. In re Marx's Estate, 106 App. Div. 212, 94 N. X. Supp. 151 (2d Dep't 1905). When the nomination is agreed to by the nominee, the nomince is said to become a partner and as such becomes entitled to the incidents of that status; cf. Byrne v. Reid, [1902] 2 Ch. 735; see also Downs v. Coilins, 6 Hare 418 (1848).

38. See Wild v. Davenport, 48 N. J. L. 129, 137, 7 Att. 295, 299 (1886); Downs v. Collins, 6 Hare 418, 441 (1848). See also notes 20 and 21 supra.

39. See Byrne v. Reid, [1902] 2 Ch. 735, 743; see also note 22 supra.

40. See note 43 infra, where the nominee's refusal to continue resulted in liquidation of the business. The result would seem to be the same where it is the survivor who refuses to carry on the enterprise. 
lifetime, the nominee's failure to consent to become a successor partner will subject the decedent's estate to an action for damages for breach of contract. ${ }^{41}$ This is because the decedent agreed that his nominee would continue the business in partnership with the survivor, and this agreement has not been kept. But the nominee would not be required specifically to perform the agreement. Ordinarily he is not a party to the continuation arrangement, and the hazards of the partnership status are such that they will not be imposed upon one who has not agreed to become a partner and who is unwilling to do so. ${ }^{42}$ And where the nominee refuses to carry on the business, the survivor has no right to require that the decedent's interest be left in the enterprise. A contrary result would be improper because the decedent partner may reasonably be supposed to have intended that the business would be continued by two persons acting in concert and not by one alone. He might well have been unwilling to entrust the enterprise to the sole management of his surviving partner. Winding up of the business will therefore be the consequence of the nominee's refusal to abide by the terms of the agrecment. ${ }^{43}$

\section{Liabilities Arising from a Continuation of the Enterprise}

A. Insulation of decedent partner's general estate from liabilities of continued business. The extent to which agreements for the continuation of a business after the death of a partner may subject a decedent partner's general estate to future risks has an important bearing upon the practical utility of such arrangements. If a continuation of the enterprise for the benefit of the decedent's estate were automatically to subject the entire estate to liability for partnership debts incurred after the partner's denth, this disadvantageous consequence of the arrangement might be sufficient to outweigh its virtues. If, on the other hand, the extent of the liability of the decedent's estate should be subject to adequate control, the desirability and practicability of the continuation agreement would be greatly increased.

The decisions reveal that the courts have looked benignly upon partnership agreements for continuation of the enterprise for the benefit of a decedent partner's estate and that they have gone far to assure the realization of the advantages which have been sought. The prevailing view is that partners may arrange to have their enterprise continued after

41. See Lancaster v. Allsup, 57 L. T. 53, 54 (Ch. D. 1887) ; Downs v. Collins, 6 Hare 418 (1848); Phillips v. Blatchford, 137 Mass. 510, 515 (1884).

42. Lancaster v. Allsup, 57 L. T. 53 (Ch. D. 1887). See Wild v. Davenport, 48 N. J. L. 129, 136, 7 At1. 295, 299 (1886) ; Downs v. Collins, 6 Hare 418, 438 (1848); Edgar v. Cook, 4 Ala. 588,590 (1843).

43. Lancaster v. Allsup, 57 L. T. 53 (Ch. D. 1887); Kershaw v. Matthews, 2 Russ. 62 (1826) ; Downs v. Collins, 6 Hare 418 (1848). 
the death of a member without subjecting the decedent's general estate to claims of subsequent creditors. The extent to which the latter's general estate will become liable to such creditors is subject to control. The partners may arrange, for example, that the property of a deceased member which is to remain subject to the risks of the business shall be limited either to the decedent's interest in the business as it existed at the time of his death ${ }^{44}$ or to such greater or lesser amount as may be agreed upon. ${ }^{45}$ The former is probably the more common type of arrangement. It is said that the general estate ${ }^{40}$ may be insulated against future risks because the rights of subsequent creditors are controlled by the terms of the agreement of continuance and not by common-law principles of partnership. ${ }^{47}$ If the agreement contemplates that the rights of subsequent creditors shall be confined to the assets of the continued firm insofar as the decedent's estate is concerned, this intention forms the measure and extent of their rights. ${ }^{48}$ Third persons dealing with the continued enterprise are therefore bound to inquire as to the extent of the authority conferred by the continuation agreement; otherwise they extend credit at their own risk. ${ }^{49}$

44. Wilcox v. Derickson, $168 \mathrm{~Pa}$. 331, 31 Atl. 1080 (1895); Stewart v. Robinson, 115 N. Y. 328, 22 N. E. 160 (1889) (the receipt of profits of continued business by estate did not make it liable as partner or otherwise); Labouchere v. Tupper, xi Mfoore P.C.C. 198 (1857) ; Cook v. Adm'r of Rogers, 3 Fed. 69 (C. C. S. D. Ohio 18s0). But see Blodgett v. American Nat. Bank, 49 Conn. 9, 26 (18S1); Kottwitz v. Alexander's Ex'r, 34 Tex. 688 (1869). In Jones v. Walker, 103 U. S. 444,446 (1880) (continuation under will) the Court suggested that if any of the corpus of the partnership estate is paid to a beneficiary, creditors would be able to recover against the recipient to the extent of the payment. This seems clearly correct, as the corpus of capital left in the business can be regarded as charged with the debts of the continuing enterprise. Non-liability on the part of decedent's general estate has also resulted where the enterprise was continued under testamentary authority of the deceased partner. Jones v. Walker, supro; Hagan v. Barksdale, 44 Miss. 186 (1870) (individual); Roessler's Estate, 5 Pa. Dist. 776 (1896) ; Smith v. Ayer, 101 U. S. 320 (1879) ; Brasfield v. French, 59 Miss. 632 (1882); Cutbush v. Cutbush, 1 Beav. 184 (1739); Ex furfe Richardson, 3 Madd. 139 (1818) (sole trader); Ex parte Garland, 10 Ves. 110 (1804) (individual). See Steiner \& Lobman v. Steiner Land \& Lumber Co., 120 Ala. 128, 144, 26 So. 494, 498 (1897). But see Eisenstadt Jewelry Co. v. Mississippi Valley Trust Co., 72 Mlo. App. 514 (1897).

45. See Burwell v. Mandeville's Ex'r, 2 How. 560,576 (U. S. 1844); Huber v. Wood, $14 \mathrm{~Pa}$. C. C. 13, 18 (1894). Authority to increase the amount of capital in a continued enterprise, which is conferred upon a person who declines to act as executor, cannot be exercised by the administrator ctm tesiamento cmmexo. Cf. Cutbush v. Cutbush, 1 Beav. 184 (1739).

46. The term "general estate" is used here to describe that portion of a partner's assets which is exclusive of his interest in the partnership.

47. See Wilcox v. Derickson, $168 \mathrm{~Pa} .331,338,31$ Atl. 1080, 1082 (1895).

48. See cases cited note 44 supra.

49. Compare Burwell v. Mandeville's Ex'r, 2 How. 560, 576 (U. S. 1844); Hagan v. Barksdale, 44 Miss. 186, 191 (1870). This accords with the general rule that a partner's death gives notice to the world of the dissolution of the firm. 1 Rowley, PartikesSHIP (1916) $§ 594$. It is apparently immaterial that the business is conducted without a 
Subsequent creditors may, however, charge a decedent partner's general estate with their claims when this was intended by the continuation agreement. ${ }^{50}$ But the intention must be clearly shown, ${ }^{51}$ and doubts in this connection are not likely to be resolved in behalf of creditors who are usually favored in other situations. It seems safe to say that in most jurisdictions the general estate will not be bound in the absence of express declaration of an intention to bind the estate.

The lengths to which the courts will go in protecting the decedent's estate, even where the justification is slight, is illustrated by Stewart $\boldsymbol{~}$. Robinson. $^{52}$ This case held that a continuation agreement, which provided that a decedent partner's estate should bear the same share of business losses as the decedent assumed during his lifetime, manifested no intention to subject the latter's general estate to the claims of subsequent creditors. An interpretation of this language which seems more natural leads to an opposite conclusion. ${ }^{63}$ The court's rather astonishing conclusion was reached on the theory that the language of the agreement manifested no clearly defined intention to subject the general estate to claims of subsequent creditors, and that a decision holding the general estate liable would cause serious inconvenience and hardship because of the practical necessity or desirability of postponing the distribution of the estate until all debts of the continued business were paid. ${ }^{54} \mathrm{~A}$ dece-

change in name. Stewart v. Robinson, 115 N. Y. 328, 22 N. E. 160 (1889); Wilcox v. Derickson, $168 \mathrm{~Pa}$. 331, 31 At1. 1080 (1895). Some jurisdictions assert, however, that death of a partner does not necessarily dissolve the partnership. See note 98 infra. If this view were carried to its logical conclusion, death of a partner would not operate to give notice of dissolution.

50. Compare Davis v. Christian, 15 Gratt. 11, 33 (Va. 1859); Gibson v. Stcvens, 7 N. H. 352, 356 (1834) ; see Wilcox v. Derickson, 168 Pa. 331, 336, 31 Att. 1080, 1081 (1895). In Blodgett v. American Nat. Bank, 49 Conn. 9, 26 (1881) it is saicl that the decedent's estate is liable for subsequent debts without regard to the decedent's intention. A provision in a continuation agreement that subsequent partnership debts are to be paid out of the assets of the continued venture has been held inconsistent with an intention to bind the decedent's general estate. See Hagan v. Barksdale, 44 Miss. 186, 194 (1870); cf. Willis v. Sharp, 113 N. Y. 586, 590, 21 N. E. 705, 706 (1889) ; Brasfield v. French, 59 Miss. 632, 637 (1882) ; Ferris v. Van Ingen \& Co., 110 Ga. 102, 108, 35 S. E. 347, 350 (1899); cf. Phillips v. Blatchford, 137 Mass. 510, 514 (1884).

51. See Stewart v. Robinson, 115 N. Y. 328, 335, 22 N. E. 160, 161 (1889) ; cf. Ferris v. Van Ingen \& Co., 110 Ga. 102, 108, 35 S. E. 347, 350 (1899) ; Roessler's Estatc, 5 Pa. Dist. 776, 778 (1896) ; Burwell v. Mandeville's Ex'r, 2 How. 560,577 (U. S. 1844).

52. 115 N. Y. 328,22 N. E. 160 (1889) ; cf. M'Neillie v. Acton, 4 De G. M. \& G. 744 (1853); Burwell v. Mandeville's Ex'r, 2 How. 560 (U.'S. 1844). But sec Ussery v. Crusman, 47 S. W. 567 (Tenn. 1898).

53. This apparently was the view entertained by the court in Alexander's Ex'rs v. Lewis, 47 Tex. 481 (1877).

54. See Wilcox v. Derickson, 168 Pa. 331, 337, 31 Atl. 1080, 1081 (1895); Ex parte Garland, 10 Ves. 110, 119 (1804); Burwell v. Mandeville's Ex'r, 2 How. 560, 577 (U. S. 1844); M'Neillie v. Acton, 4 De G. M. \& G. 744, 753 (1853); Roessler's Estate, 5 Pa. 
dent, the court held, ordinarily would not be deemed to intend such a consequence in the absence of a clearly indicated intention to that effect. ${ }^{55}$

The opposite conclusion could have been reached on the theory that it would be unreasonable to believe that a surviving partner, in the absence of clear language to the contrary, would agree to carry on the business and divide the profits with decedent's estate unless the latter were to assume its share of any loss suffered. It may be conceded, though, that the court's argument has considerable force where the language of the continuation agreement is ambiguous or where the period for which the business is to be continued extends beyond a reasonable period of time for the distribution of a decedent partner's general estate. But the argument has not been confined to such situations; it has not only been used where the language of the agreement gave little room for interpretation $^{56}$ but also where the unexpired term was of such short duration as not to require undue postponement of distribution of the estate. 57 The result reached in Stewart $v$. Robinson is open to the further criticism that persons extending credit to the continued enterprise are likely to be misled. They would naturally assume that the terms of the continuation agreement bound the decedent's general estate for the debts of the enterprise.

The courts' tendency to resort to strained and artificial reasoning in order to insulate the general estate from subsequent risks of the business may be observed in another connection. It has been noted already that the arrangement may be one which contemplates continuation of the business by the survivor alone. It has been urged in these circumstances that a deceased partner could not have intended that his entire estate should become subject to the liabilities of the continued business venture because no right of control over the business was reserved to his executors. ${ }^{58}$ Such an argument obviously is not of general validity. The duties of an executor frequently do not require the exercise of any considerable degree of business judgment. On the other hand, the high degree of confidence which one partner necessarily reposes in the business judgment of an associate who is to have sole control of the business after his death makes it not at all unnatural that he should, at least in

Dist. 776, 777 (1896). If distribution of the estate were not held up, equal if not greater hardship would result if recipients of the estate were required many years later to yicld their shares to creditors; cf. Roessler's Estate, supra at 777 ; Ex forle Garland, supro at 119.

55. See Wilcox v. Derickson, $168 \mathrm{~Pa}$ 331, 31 Atl. 1080 (1896); cf. Burwell v. Mandeville's Ex'r, 2 How. 560, 577 (U. S. 1844).

56. Compare Burwell v. Mandeville's Ex'r, 2 How. 560 (U. S. 1844).

57. Ibid. (continuation authorized by will; authority for continuance had one year and two months to run).

58. See Burwell v. Mandeville's Ex'r, 2 How. 560,580 (U. S. 1844) (continuation authorized by will). 
some instances, repose greater confidence in him than in one whom he might name as his executor.

B. Liability of the survivor, decedent's personal representative, and heirs where the business is continued by survivor alone. A surviving partner who, pursuant to the terms of a continuation agreement, carries on the business after the death of an associate is personally responsible not only for obligations arising prior to his associate's death, but also for the debts which are incurred thereafter. ${ }^{\circ 0}$ His liability for the stibsequent debts is that of a principal, but he is entitled to exoneration where he pays more than his share of the business debts. The amount of exoneration to which he is entitled is limited by the terms of the continuation agreement. If the agreement contemplates that his right of exoneration shall be limited to the interest of the decedent remaining in the continued enterprise, this intention is controlling. ${ }^{60}$ But if it contemplates that the general estate of the decedent shall be responsible for the debts of the continued business, then the right of exoneration extends to the general estate. ${ }^{01}$

As neither the decedent's executors ${ }^{62}$ nor his legatees ${ }^{63}$ become partners in the continued enterprise where the agreement for continuation provides that the business shall be carried on by the survivor alone, they

59. Tenney, Ballister \& Co. v. New England Prot. Union, 37 Vt. 64 (1864); af. Pitkin v. Pitkin, 7 Conn. 307 (1828).

60. See Wild v. Davenport, 48 N. J. L. 129, 137, 7 Atl. 295,299 (1886); cf. Pitkin v. Pitkin, 7 Conn. 307 (1828); Huber v. Wood, 14 Pa. C. C. 13 (1894). Danger exists, in the absence of a clear-cut provision to the contrary, that if the resources of the continucd enterprise are not sufficient to pay creditors and the survivor is required to make good a deficiency out of his own pocket, a covenant will be implied on the part of the estate to reimburse the survivor for the amount paid in excess of the latter's pro rata sharc. Phillips v. Blatchford, 137 Mass. 510 (1884).

61. Phillips v. Blatchford, 137 Mass. 510 (1884). Cf. Huber v. Wood, 14 Pa. C. C. 13 (1894).

62. Richter v. Poppenhusen, 39 How. Pr. 82 (Sup. Ct. 1870), aff'd, 42 N. Y. 373 (1870); Wild v. Davenport, 48 N. J. L. 129, 7 Atl. 295 (1886); cf. Stewart v. Robinson, 115 N. Y. 328, 22 N. E. 160 (1889). But in Edgar v. Cook, 4 Aln. 588, 590 (1843) it is suggested that an executor becomes a partner merely by leaving assets of the decedent in the business. Accord, Holme v. Hammond, 7 Exch. 218 (1872). But see Ex parte Garland, 10 Ves. 110, 121-122 (1804).

63. This follows inevitably from the fact that, absent an intention on the part of the decedent to bind his general estate, the latter is not liable for subsequent debts of the enterprise. See p. 210 stipra. Protecting the estate against the claims of creditors would be foolish if the distributees were later on to be held liable. Cf. Pitkin v. Pitkin, 7 Conn. 307 (1828). Contra: Nave v. Sturges, 5 Mo. App. 557 (1878). Uniforar Partnersini ACT, $\S 7(4)$, provides that "The receipt by a person of a share of the profits of a business is prima facie evidence that he is a partner in the business, but no such inference shall be drawn if such profits were received in payment: . . . (c) as an anntity to a widow or representative of a deceased partner." 
are therefore not liable either to prior ${ }^{04}$ or subsequent creditors. ${ }^{65}$ The fact that the decedent's interest vests in the executor ${ }^{\circ 6}$ and that the latter leaves the decedent's interest in the business ${ }^{67}$ and receives its profits for the benefit of the estate does not make him a partner. ${ }^{68}$ Nor does he become a partner through inspecting the books of the business. ${ }^{\text {ca }}$ If, however, he should through agreement or conduct assume the status of a partner, he would, of course, become liable as such. ${ }^{70}$

C. Liabilities of decedent's executor and other successor partners where business is conducted jointly by them and survizor. It has already been noted that arrangements for continuation of the enterprise after the death of a partner may contemplate the introduction of a new or successor member to replace the decedent. The person designated as successor partner often is the decedent's executor, ${ }^{71}$ although, of course, other persons may be named. Although such a successor is not personally entitled to profits of the continued business, he becomes liable as a partner to creditors whose claims arise after he has assumed this status. ${ }^{72}$ If he is required to pay any such claims out of his personal assets, he will, however, be entitled to exoneration to the extent that the decedent's estate is embarked in the continued enterprise. ${ }^{73}$ If, on the other hand, the claims concerned existed at the time of the death of the former

64. Mattison v. Farnham, 44 Minn. 95, 46 N. W. 347 (1890).

65. Richter v. Poppenhusen, 39 How. Pr. 82 (Sup. Ct. 1870), off'd, 42 N. Y. 373 (1870) (executors); cf. Owens v. Mackall, 33 Mfd. 382 (1870) (executors); Jones v. Walker, 103 U. S. 444 (1880).

66. See Wilcox v. Derickson, $168 \mathrm{~Pa} .331,339,31$ Atl. 1080, 1082 (1895).

67. Wild v. Davenport, 48 N. J. L. 129, 7 Atl. 295 (1886); Richter v. Poppenhusen, 39 How. Pr. 82 (Sup. Ct. 1870), aff'd, 42 N. Y. 373 (1870); cf. Owens v, Mlacliall, 33 Md. 382 (1870); Bacon v. Pomeroy, 104 Mass. 577 (1870). But see Edgar v. Coote, 4 Ala. 588 (1843).

68. Butcher v. Hepworth, 115 N. Y. 328, 22 N. E. 163 (1859); see also Richter v. Poppenhusen, 39 How. Pr. 82 (Sup. Ct. 1870), aff'd, 42 N. Y. 373 (1870). Nor does mere acceptance of profits where the enterprise is continued under the authority of a will render the recipient liable as partner. Cf. Jones v. Walker, 103 U. S. 444 (1880). But see Edgar v. Cook, 4 Ala. 588 (1843).

69. Wild v. Davenport, 48 N. J. L. 129, 7 Atl. 295 (1886).

70. Edwards v. Thomas, 66 Mo. 468 (1877). This liability attaches because the executor holds himself out as a partner. See Richter v. Poppenhusen, 39 How. Pr. 82 (Sup. Ct. 1870), aff'd, 42 N. Y. 373 (1870). The case of the executor is hard, in that he becomes liable as a partner to the full extent of his personal assets. See Ex farte Garland, 10 Ves. 110, 119 (1804).

71. Where an executor becomes a partner in a continued enterprise, he acts as a member of the partnership and not in his capacity as executor. Columbus Watch Co. v. Hodenpyl, 135 N. Y. 430, 32 N. E. 239 (1892).

72. See Avery \& Son v. Meyers, Houseman \& Co., 60 Mriss. 367, 371 (1882) ; Wild v. Davenport, 48 N. J. L. 129, 137, 7 Atl. 295, 299 (1886); Willis v. Sharp, 113 N. Y. 586, 591, 21 N. E. 705, 706 (1889); Lindley, Partsersuip (10th ed. 1935) 725.

73. See p. 214 supra. 
partner, the latter's successor would not be personally liable in the absence of evidence of an intention on his part to assume past debts of the business. ${ }^{74}$ Where the agreement for continuance expressly contemplates that a designated person shall become a partner, less evidence will probably be required to establish that he has assumed the partnership status than if no such provision existed. Thus, where an agreement contemplated the introduction of decedent's executor as successor partner, the executor's silence and his failure to withdraw the estate's assets from the business have been held strong evidence that he had assumed the partnership status. ${ }^{75}$ This result seems sound, because under the circumstances the executor's conduct can be fairly interpreted as manifesting his intention to become a partner. If he did not intend to become a partner, it would have been natural for him so to declare.

\section{Rights of Creditors Against Assets of the Continued Enterprise}

A. Where claims are incurred after the death of a partuer and the enterprise is contimued by the surviving partner in association zerith a successor partner. ${ }^{76}$ The practicability of having a successor partner continue a business after the death of one partner in the interest of his beneficiaries is determined to some extent by the court's interpretation of creditors' rights. If the scheme seriously curtails creditors' rights, the arrangement will not be satisfactory in those ventures where credit must be readily available.

Creditors of a firm which is continued pursuant to such an arrangement are, of course, able to hold the surviving partner and the successor partner personally liable on any obligations which they incur in carrying on the enterprise. Hence, if the continuation arrangement adversely affects the rights of this type of creditor, it is because it affects his ability to reach the assets of the continued venture, as distinguished from the personal assets of those continuing the enterprise. The question of his ability to reach the assets of the continued business will assume its greatest importance when the personal resources of the continuing partners are

74. Mattison v. Farnham, 44 Minn. 95,46 N. W. 347 (1890). The survivor clearly would be liable for debts incurred in the interval between the death of a member and the time when the latter's nominee assumed his status as successor partner. It would seem that the successor partner should not be held liable for such debts in the absence of a personal agreement of assumption. In the unlikely event that he were held personally responsible for the intervening debts, he would be entitled to indemnity out of the part of decedent's estate that was embarked in the enterprise. See p. 214 supro.

75. Morris v. Harrison, Colles 157 (1701) ; Story, ParTnership (6th ed. 1868) 337.

76. The rights of creditors of this type against the decedent's estate and the survivor respectively have been discussed pp. 210-215 supra. 
inadequate to meet the total of their firm and personal obligations. ${ }^{\text {it }}$ This will happen frequently by reason of the common practice of partners of placing all or the greater portion of their wealth in their businesses.

The right of the firm creditor to reach firm assets would be reasonably clear if partnerships arising from continuation agreements possessed legal incidents similar to those of partnerships formed by voluntary inter vivos changes. It is elementary partnership law that persons who extend credit to a successor partnership formed in the latter way are able to reach firm assets in an action at law and subject them to the payment of their claims. ${ }^{78}$ It is entirely possible, though, that different consequences may follow where the continuation agreement provides for the introduction into the enterprise of a successor partner who is to take the place of a decedent member in the interest of the latter's beneficiaries. Here there is created a relationship between the successor partner and the beneficiaries which resembles a pure trust relationship, with the beneficiaries of the scheme comparable to the cestui que trust and the successor partner comparable to a trustee of the dead member's interest. ${ }^{70}$

While no cases have been found which directly hold that a typical trust results in this situation, there are suggestions in the opinions which point in this direction. ${ }^{80}$ Lindley apparently entertains this view, although he is not satisfactorily explicit on the point. ${ }^{81}$ There is also authority to the effect that an executor who continues the business of a sole trader pursuant to the latter's testamentary direction becomes a trustee for the decedent's beneficiaries. ${ }^{82}$ It may therefore be urged that. as a trust relationship results in the latter situation, a similar relationship results where a continuation arrangement of the type under consideration goes into effect after a partner's death. This question, however, is still open and an answer should not be given by resort to superficially relevant analogies or without a careful weighing of practical consequences.

Under trust law, creditors of a trustee who has incurred expenses on behalf of his estate cannot reach the trust assets and subject them

77. Surviving partners are, of course, authorized to use assets of the continued enterprise to pay properly incurred debts. Cf. Ferris v. Van Ingen \& Co., $110 \mathrm{Ga} .102$. 35 S. E. 347 (1900) ; Davis v. Christian, 15 Gratt. 11 (Va. 1859); see also Costello v. Costello, 209 N. Y. 252, 260, 103 N. E. 148, 151 (1913); Vincent v. Martin, 79 Ala. 540. 545 (1885).

78. Uniform Partnership Act §41; Crane, Partakership (1938) 386.

79. This would not be true, of course, where the successor partner is given or buys the decedent's interest.

80. See In re Flavell, 25 Ch. D. 89, 93 (1883); Page v. Cox, 10 Hare 163, l6S (1851) ; Ehrmann v. Ehrmann, 72 L. T. 17 (1895).

81. Lindley, PartNership (10th ed. 1935) 728, 730.

82. In re Evans, 56 L. T. 768 (1887); Dowse v. Gorton, [1891] A. C. 190; In re Frith [1902] 1 Ch. D. 342; In re Johnson, 15 Ch. D. 548 (1880); Jacob, Trusts for Continuing a Decedent's Business (1932) 18 Iowa L. REv. 43. 
to the payment of their claims in an action at law. ${ }^{83}$ Hence, if it should be held that a continuation arrangement creates a trust relationship, creditors of the continued firm would probably be unable to reach its assets in an action at law. ${ }^{84}$ One result of such a view would be to force creditors of the continued firm to work out their rights against the latter's assets through the trustee's equitable right of exoneration. ${ }^{85}$ This would mean that the extent to which such creditors would be able to reach the interest of the estate in the continued business would be reduced by the amount which the trustee might be-indebted to it. ${ }^{80} \mathrm{~A}$ further consequence would be to deprive creditors of the privilege of attaching firm assets in actions against the continued firm. ${ }^{87}$

It seems unsound to make the rights of creditors depend upon the state of accounts existing between the successor partner and the beneficiaries of his activities. The growing policy of the law to subject entrepreneur capital to the risks of the enterprise has manifested itself, among other ways, in the enactment of employment insurance statutes and in the development of the doctrine of respondeat superior and its marked extension in workmen's compensation statutes. ${ }^{88}$ Where the usual type of partnership or corporation is concerned, embarked capital is stubject in its entirety to the claims of creditors, and there seems to be no sound reason why an exception should be made in the situation under considera-

83. 2 Scotr, Trusts (1939) 1499; Stone, A Theory of Liability of Trust Estates for the Contracts and Torts of the Trustee (1922) 22 CoL. L. REv. 527.

84. It can, of course, be contended that the association of the surviving partner and the designated successor for the purpose of continuing the enterprise restilts in the formation of a new partnership having the usual partnership characteristics, and that new creditors of the continued enterprise will therefore be entitled to be paid before anything can be returned to the deceased partner's estate. This point of view scems to assume the point at issue. The question is whether this type of situation is controlled by the usual doctrines of partnership law or whether these doctrines are modified by a trust relation.

85. In re Johnson, 15 Ch. D. 548 (1880); Hewitt v. Pheips, 105 U. S. 393 (1881); 2 SCOTT, TRUsts (1939) 1502.

86. In re Evans, 56 L. T. 768 (1887); 2 ScoTr, Trusts (1939) 1510. The result indicated in the text would not seem to differ if the enterprise were continued by a sole surviving partner. If the trust point of view should prevail, the surviving partner, instead of the successor, would be the trustee of the decedent's interest as well as absolute owner of his own interest.

87. Attachment may be invoked only in connection with a type of proceeding which is historically known as a legal action. Drake, Atracnments (7th ed. 1801) §9. Abolition of the formal distinction between law and equity in the code states does not change this rule. Pomeroy, Cone Remedies (4th ed. 1904) \$37. But see Columbus Watch Co. v. Hodenpyl, 135 N. Y. 430, 32 N. E. 239 (1892) (statement, where partnership was continued under a will, that creditors of continued business possessed the ustul rights of partnership creditors).

88. Stone, $A$ Theory of Liability of Trust Estates for the Contracts and Torts of the Trustee (1922) 22 CoL. L. Rev. 527. 
tion. ${ }^{89}$ An analogy is available to buttress the conclusion that a strict trust relation should not be regarded as arising where this type of enterprise is concerned. Where one member of a typical partnership dies. legal title to firm personalty vests in the survivors, ${ }^{00}$ whose duty it is to wind up the business, pay obligations of the firm, and distribute what is left among those entitled. ${ }^{91}$ Creditors of the old partnership may sue the survivor in an action at law for unpaid debts, attach firm property and subject it to the payment of their claims. ${ }^{92}$ The survivors are not regarded as trustees for the estate of the deceased partner despite the fact that they hold legal title to firm personalty pending a winding up of the business. ${ }^{93}$ Indeed, it has not only been said that the survivors are not trustees in these circumstances, but that firm creditors have no equitable remedy whatsoever against them so long as insolvency does not intervene..$^{94}$ If surviving partners do not become strict trustees in such circumstances under partnership law, it seems plausible to urge that a successor partner who becomes such under an arrangement for partnership continuation likewise should not be regarded as becoming a trustee under partnership law.

B. Where claims are incurred prior to the death of a partner and the enterprise is continued by the survizing partner in association with a successor partner. There remains to be considered the manner in which the continuation agreement may affect the rights of persons who become partnership creditors before the death of a partner. ${ }^{05}$ Assets of both

89. Mrany cases seem tacitly to assume that the rights of creditors of the continued firm are not contingent on the state of accounts between a successor partner and the estate he represents. See cases cited in note 44 supra. Note, however, the statement in Richter v. Poppenhusen, 39 How. Pr. 82 (Sup. Ct. 1870), aff'd, 42 N. Y. 373 (1870) that creditors of the continued firm would be required to resort to equity in order to subject the assets of the continued enterprise to their claims. Even if this view prevails, it would not necessarily follow that such creditors would be required to work out their rights through the successor partner's right of exoneration.

90. Barry v. Briggs, 22 Mich. 201, 206 (1871); Butcher v. Hepworth, 115 N. Y. $328,343,22$ N. E. 163 (1889). A partner's share in real property descends to his heirs at common law and if it is necessary that the property be used to pay creditors, equity will compel its conveyance. Shanks v. Klein, 104 U. S. 18 (1881).

91. Crane, Partnership (1938) 367.

92. Krueger v. Speith, 8 Mont. 482, 20 Pac. 664 (1859); cf. Costello v. Costello, 209 N. Y. 252,1 , N N. E. 148 (1913).

93. Krueger v. Speith, 8 Mont. 482, 20 Pac. 664 (1859); Sheffield v. Key \& Rials, 14 Ga. 537 (1854); see Roach v. Brannon, 57 Aliss. 490, 499 (1879); 2 Rowley, PartNERSHIP (1916) $\$ 835$.

94. Roach v. Brannon, 57 Miss. 490, 500 (1879).

95. It is assumed that at the time of the death of a member, both partners and the continued firm are solvent. Situations in which a transfer of a decedent's partner's interest would work a fraud on the rights of prior creditors are outside the scope of this article. 
the decedent's estate and the surviving partners are, of course, liable to such creditors. ${ }^{96}$ The doubtful question concerns the rights of the latter against the assets of the continued enterprise. Aside from the aspect of technical legal procedure, this matter will be important chiefly where the assets of the surviving partners become insufficient to pay their obligations and when the time has expired for proof of claims against the estate of the deceased partner. As an original proposition, it would seem that such prior creditors should be able to reach and subject the assets of the continued venture to the payment of their claims. Their natural equities in such assets are as strong as those of persons who become creditors of the new or continued firm, ${ }^{97}$ and their position in this respect is strengthened by the fact that the usual continuation agreement clearly intends that the assets of the continued enterprise shall be used to satisfy their claims as well as those of persons who become firm creditors at a later date. But it cannot be asserted confidently that the prior creditors will be able to reach the assets of the continued firm. Definitive decisions are lacking, and the skein of the common law, as it affects partnership creditors, is tangled and confusing.

It is clear, despite the existence of an agreement of continuance, that the death of a partner necessarily results in a dissolution of the old partnership, and, where it is carried on by the survivor in association with a successor, in the formation of a new partnership. ${ }^{08}$ This dissolution

96. 2 RoWley, PartNership (1916) $\$ 630$.

Liability of the decedent partner's estate may sometimes raise an important problem with respect to the practicability of resorting to the use of the continuation agreement. If firm creditors existing at the death of the partner should prove their claims against the decedent's estate, payment of these claims would obviously deplete cstatc assets then available for distribution. While the estate would be entitled to a pro rata exoneration against the survivor, it is doubtful that it could require reimbursement prior to the expiration of the continuation agreement. This conclusion is suggested by the analogy that a partner cannot, without dissolving the firm, require payment of an obligation owing to him by the firm before the end of the partnership term. GllmorE, PARTNERSHIP (1911) 504. Such a result might, of course, affect not only the amount that the decedent's beneficiaries might ultimately receive from him, but also the time when distribution of the estate may be made.

97. This is also the view of the Uniform Partnership Act, $\$ 41$.

98. There is disagreement, at least in the language of the decisions, as to whether "dissolution" of a partnership results from the death of a partner where the enterprise is thereafter continued pursuant to the provisions of a previous agreement or by testamentary direction of the decedent member. One view regards the death of a partner as necessarily causing a dissolution of the partnership and treats the continued firm as a new partnership. Andrews v. Stinson, 254 Ill. 111, 124, 98 N. E. 222, 225 (1912) ; Kennedy v. Porter, 109 N. Y. 526, 549, 17 N. E. 426, 434 (1888); Hornaday v. Cowgill, 54 Ind. App. 631, 639, 101 N. E. 1030, 1034 (1913); Wilcox v. Derickson, 168 Pa. 331, 335, 31 At1. 1080 (1895); Parsons, Partnersuip (4th ed. 1893) 433, 439. The other view is that death does not cause a dissolution where there is an agreement for continutation of the enterprise. See Evans v. Watts, 192 Pa. 112, 115, 43 Atl. 464 (1899); Kott- 
may seriously affect the rights of persons who were creditors at the time of dissolution. Its consequence may be illustrated by reference to an analogous situation. A partnership may, for example, be dissolved voluntarily by agreement during the lifetime of its members and the enterprise continued either by some of the old members or by the old members together with one or more new partners. Creditors of the old partnership do not in this situation become creditors of the new firm unless it assumes their debts. ${ }^{99}$ Where no such assumption occurs, creditors of the old firm are unable to reach the assets of the continued enterprise. ${ }^{100}$ Where, however, such debts are assumed, those jurisdictions which recognize third party beneficiary contracts permit creditors of the old firm to reach and subject the assets of the continued firm to the payment of their claims. $^{101}$

On comparable reasoning, it would seem that creditors of the original firm should be able to reach the assets of an enterprise which is continued after the death of a partner under authority of the partnership contract. The clear intention of this type of continuation agreement is that the assets of the continued firm shall be used to pay all its legitimate debts, whether incurred before or after the death of a member. ${ }^{102} \mathrm{~A}$ third party beneficiary contract, which would permit such prior creditors to reach the assets of the continued venture, seems to be implicit in these arrangements. ${ }^{103}$

witz v. Alexander's Ex'r, 34 Tex. 689, 712 (1869); Lincoln v. Orthwein, 120 Fed. 8\$0, 883 (C. C. A. 5th, 1903); Parnell v. Thompson, 81 Kans. 119, 136, 105 Pac. 502, 503 (1909) ; Rand v. Wright, 141 Ind. 226, 233, 39 N. E. 447, 450 (1894). In Missouri both views are entertained. Exchange Bank v. Tracy, 77 Mo. 594, 600 (1883); Edwards v. Thomas, 65 Mo. 468, 481 (1877). This conflict of opinion is probably more apparent than real. The cases which state that death dissolves a partnership assume as their major premise that a change in the membership of a partnership necessarily results in the formation of a new partnership. As the old firm no longer exists, it is natural to regard it as dissolved. See Exchange Bank v. Tracy, supra at 600; Andrews v. Stinson, supro at 124. On the other hand, those courts which assert that death does not necessarily dissolve a partnership which is continued by agreement after the death of a member, probably mean only that in such circumstances death does not require winding up the enterprise. Certainly this is true of Leaf's Appeal, $105 \mathrm{~Pa} .505$ (18S4).

99. Crane, Partnership (1938) 386.

100. 1 Rowley, Partwership (1916) \$559. All the former partners remain, of course, personally liable for unpaid debts of the old firm. 1 RowLEY, supra at $\$ 558$.

101. Gilarore, Partnership (1911) 248.

102. See note 77 supra.

103. This result, although not the reasoning, accords with the viev expressed in Costello v. Costello, 209 N. Y. 252, 260, 103 N. E. 148, 151 (1913). While the enterprise here concerned was continued after the death of a partner by testamentary authority of the decedent member, no sufficient reason appears why a different result would be reached where the enterprise was continued by agreement instead. See also Kilhoffer $v$. Zeis, 109 Misc. 555, 568, 179 N. Y. S. 523, 530 (1919), aff'd, 196 App. Div. 922, 187 N. Y. Supp. 940 (4th Dep't 1921); In re Simpson, 9 Ch. 572 (1874). From the point of 
The foregoing discussion involves a consideration of what may be loosely denominated as the substantive rights of prior creditors of the continued enterprise. It does not deal with the forum in which such rights may be asserted. This question will not arise in those jurisdictions where the reformed procedure has been adopted, as all litigants seek their remedies in the single integrated court which has replaced the old dual system characterized by separate courts of law and equity. ${ }^{104}$ The problem of the proper forum in which to maintain actions remains important, however, in those jurisdictions which still make a formal distinction between actions at law and suits in equity. ${ }^{105}$ In these latter jurisdictions, creditors of the old firm would be unable to maintain a purely legal action against the new firm where a successor partner, representing the decedent's estate, has been introduced into the continued enterprise. This is because a judgment at law in favor of the creditors, if the new firm were sued and held liable, would bind the successor partner along with the members of the old partnership. In the absence of an express agreement by the successor partner, it would be unreasonable to assume that he intended to become personally responsible for the earlier debts. ${ }^{100}$ And in the absence of such assumption by the successor, it would be difficult to evolve a basis for making him personally liable. Hence, where the reformed procedure does not obtain, prior creditors probably must sue in equity in order to reach the firm assets. ${ }^{107}$

$$
\text { * } * *
$$

The partnership continuation agreement has intercsting possibilities which should not be overlooked by small entrepreneurs who desire both to minimize taxes through the use of the partnership and to protect their estates against the heavy financial losses frequently suffered through

view expressed in the text, such cases as Dowse v. Gorton, [1891] A. C. 190, and Ex partc Garland, 10 Ves. 110 (1804), have no relevancy with respect to the rights of creditors of a business continued pursuant to the type of arrangement under consideration as they do not involve enterprises continued under a contractual arrangement.

104. Clark, Code Pleading (1928) 18. See also note 105 infra.

105. The distinction between actions at law and suits in equity is maintained in Alabama, Arkansas, Delaware, Iowa, Kentucky, Mississippi, New Jersey, Oregon, Temuessee and Vermont. Clark, Code Pleading (1928) 20.

106. Compare Mattison v. Farnham, 44 Minn. 95,46 N. W. 347 (1890).

107. The problem of the proper forum for suit also will arise where an agreement of continuance contemplates that the enterprise shall be continued by the surviving partner alone. In this situation, in contrast with that which involves a successor partner, the reason is lacking for compelling prior creditors to work out their rights in equity. The enterprise has no new member who has failed to assume its past obligations (sce p. 206 supra). A surviving member of a typical partnership is liable in an action at law for debts of the old firm. See note 96 supra. This also seems true in the situation under consideration. There seems to be no reason why the continuation arrangement should affect the forum in which such creditors may seek their remedy, assuming, of course, that a strict trust does not result from the continuation arrangement. See p. 217 supra. 
the death of a partner. Where the arrangement is found adaptable to the needs of particular entrepreneurs, it has obvious advantages over both the small corporation and the partnership agreement which lacks a provision for its continuance. But the partnership continuation arrangement has definite limitations as well as advantages. In each case its projected use will require careful examination into the business and personal affairs of the entrepreneurs concerned. Such factors as the individual business abilities of the associates, the extent of their resources, and the income requirements of their families will weigh in the final decision. It seems probable, though, that many instances will develop in which the continuation agreement will be found appropriate, and the obvious advantages of this heretofore neglected partnership arrangement suggest that it is likely to have a decided appeal to an increasingly large number of business men. 